\title{
Öğretmenlerin Bireysel Yenilikçilikleri ile Öğrenci Merkezli Öğretim Yöntem ve Tekniklerini Kullanmaya Yönelik Tutumları Arasındaki İlişkinin İncelenmesi ${ }^{1}$
}

\author{
Abdullah ÇETIN \\ Dr. Öğr. Üyesi, Kahramanmaraş Sütçü İmam Üniversitesi \\ Eğitim Fakültesi, Eğitim Bilimleri Bölümü \\ abdcetin46@gmail.com \\ Orcid ID: https://orcid.org/ 0000-0003-1118-0740
}

\begin{abstract}
Öz
$\mathrm{Bu}$ araştırmanın amacı, öğretmenlerin bireysel yenilikçilik algı düzeyleri ile öğrenci merkezli öğretim yöntem ve teknikleri kullanmaya yönelik tutum düzeyleri arasındaki ilişkiyi belirlemektir. Araştırma nicel araştırma desenlerinden biri olan ilişkisel tarama modelinde yürütülmüştür. Araştırmanın evrenini, 2018-2019 eğitim-öğretim yılında Kahramanmaraş il merkezinde görev yapan öğretmenler oluştururken araştırmanın örneklemini farklı okul türlerinde görev yapan 212 kadın ve 236 erkek olmak üzere toplam 448 öğretmen oluşturmuş̧ur. Araştırmada veriler "Kişisel Bilgi Formu", "Bireysel Yenilikçilik Ölçeği (BYÖ)" ve "Öğrenci Merkezli Öğretim Yöntem ve Tekniklerini Kullanmaya Yönelik Tutum Ölçeği (ÖMÖYTKYTÖ)” kullanılarak toplanmıştır. Elde edilen verilerin analizinde SPSS 21 paket programı kullanılarak betimsel istatistiğin yanı sıra Pearson Momentler Çarpımı Korelâsyon Katsayısı hesaplanmış ve çoklu regresyon analizi yapılmıştır. Araştırmanın sonucunda öğretmenlerin bireysel yenilikçilik düzeylerinin ve öğrenci merkezli öğretim yöntem ve teknikleri kullanmaya yönelik tutum düzeylerinin "katıllyorum" düzeyde olduğu görülmüștür. Öğretmenlerin bireysel yenilikçi oluşları ile öğrenci merkezli yöntem ve teknikleri kullanmaya yönelik tutumları arasında orta düzeyde, pozitif yönde anlamlı bir ilişkinin olduğu tespit edilmiştir. Öğretmenlerin bireysel yenilikçi olmaları, öğrenci merkezli öğretim yöntem ve teknikleri kullanma tutumlarını anlamlı bir șekilde yordamakta ve toplam varyansın \%42'sini açıklamaktadır.
\end{abstract}

\footnotetext{
${ }^{1}$ Makale Geliş/Kabul Tarihi: 19.11.2019 / 20.04.2020

Künye Bilgisi: Çetin, A. (2020). Öğretmenlerin Bireysel Yenilikçilikleri ile Öğrenci Merkezli Ögretim Yöntem ve Tekniklerini Kullanmaya Yönelik Tutumlarl Arasındaki İlişkinin Incelenmesi. Kahramanmaraş Sütçü İmam Üniversitesi Sosyal Bilimler Dergisi, 17 (1), 1-20. DOI: 10.33437/ksusbd.648747
} 
Anahtar Kelimeler: Bireysel Yenilikçilik, Öğrenme Yöntem ve Teknikleri, Öğretim, Tutum.

\title{
Investigating the Relationship between Teachers' Individual Innovativeness and their Attitudes towards Using Student-Centered Teaching Methods and Techniques
}

\begin{abstract}
This study aims to determine the relationship between teachers' individual innovation perception levels and their attitudes towards using student-centered teaching methods and techniques. The relational screening model, one of the quantitative research methods, was adopted in this particular research. The sample of the study was composed of 448 teachers (212 females and 236 males) working in different schools in Kahramanmaraş city center in 2018-2019 education year. The data were collected through "Personal Information Form", "Individual Innovation Scale" and "Attitude Scale for Using Student-Centered Teaching Methods and Techniques". The data were descriptively analysed using SPSS 21.0; accordingly, the Pearson product-moment correlation coefficients were calculated and multiple regression analysis was performed. The research results indicated that the teachers' individual innovativeness levels and their attitudes towards using student-centered teaching methods and techniques were "agree”. A moderate positive relationship was found between the teachers' individual innovativeness and their attitudes towards using student-centered teaching methods and techniques. Hence, the teachers' being individual innovators significantly predicts their attitudes towards using student-centered teaching methods and techniques and explains $42 \%$ of the total variance.
\end{abstract}

Keywords: Individual Innovativeness, Instructional Methods and Techniques, Teaching, Attitude.

\section{GíRIş}

Bilim ve teknolojide meydana gelen gelişimlerle birlikte kurumlar dışsal çevrede yaşanan koşullara cevap vermek adına ürün, yapı, sistem, süreç ve stratejilerini sürekli yenilemek ve değiştirmek zorunda kalmaktadırlar (Naktiyok, 2007). Kurumlar gerçekleştirdiği yeniliklerle kapasitelerini artırmakta, performanslarını iyileştirmekte ve dinamizm yakalayabilmektedirler (Elçi, 2012). Aynı zamanda kurumlar karşı karşıya kaldıkları atalet ve durgunluğu yansitan dinozorlaşma sendromunun panzehiri olarak yenilikleri görmektedirler 
(Naktiyok, 2007). Değişim ve yenilik ihtiyacını sürekli hisseden kurumların başında eğitim kurumları gelmektedir (Arkhipova ve Kuchmaeva, 2018; Caena, 2014; Genç, 2000; Genç ve Erayman, 2007; Özdemir, 2000; Voogt ve Pelgrum, 2005 ). Bu kapsamda Türkiye'de de 2004 yılında yapılandırıcı yaklaşıma uygun eğitim benimsemiş öğretim programlarında köklü değişikliklere gidilmiştir (Ü̉nsal vd., 2019). Yapılandırmacılıkla birlikte öğretmenin görevleri tamamen farklılaşmış, meslek en büyük değişimi ve dönüşümü gerçekleştirmiştir (Bay, 2008; Bayır, 2008). Yapılandırmacı yaklaşıma göre yeniden düzenlenen eğitim programları öğretmenlere; öğrenme ve öğretme sürecine rehberlik ederken, öğrenme ortamını düzenlerken ve değerlendirme etkinliklerini planlarken program felsefesine uygun hareket etme sorumluluğu yüklemiştir (Milli Eğitim Bakanlığ [MEB], 2005).

Yapılandırmacı yaklaşım göre, bilgi öğretmenden öğrenciye doğrudan ve olduğu gibi aktarılamaz, öğrenci bilgiyi etkin bir şekilde yeniden yapılandırır ve yeni bir formata dönüştürerek alır. Öğretmen öğrencinin öğrenmesine rehberlik eder (MEB, 2005). Yapılandırmacı yaklaşım öğrenme öğretme sürecinde öğrencilerin aktif katılımını gerektiren öğrenci merkezli öğrenme yöntem ve tekniklerin kullanılmasina vurgu yapar (Akpınar ve Gezer, 2010; Karasu Avcı ve Ketenoğlu Kayabaşı, 2018; Koç, 2014; Okur Akçay vd., 2016; Ünsal, Ağçam ve Korkmaz, 2017). Ayrıca tüm öğrencilerin ilgi ve ihtiyaçlarını göz önünde bulundurarak çeşitli öğretim stratejilerinin kullanması yapılandırmacı yaklaşımın doğası gereğidir (MEB, 2005). Konunun içeriğine uygun belirlenen yöntem veya teknikle öğrencilerin akademik başarısı artmakta (Uyar Yeşilpınar ve Doğanay, 2018), ders daha akıcı ve eğlenceli hale gelmekte, zamandan tasarruf sağlanmakta (Ergani, 2010), katılım ve motivasyon artmakta, bilgi kalıcı ve dikkat çekici olmakta, öğrenme kolaylaşmaktadır (Demirkan ve Saraçoğlu, 2016; Ünsal, 2017). Ayrıca öğrenme-öğretme süreçlerinde çeşitli yöntem ve tekniklerin kullanılması öğretme-öğrenme sürecini de etkili ve basit hale getirebilmektedir (Okur Akçay vd., 2016). Bunun yanında eğitimde öğrenci merkezli yöntem ve tekniklerin kullanılması öğrencilerin ihtiyaçlarını karşılamada ve küresel bilince sahip vatandaşlar olarak yetiştirilmesinde önemli bir faktör olarak kabul edilmektedir (İlter, 2014). Benzer gerekçelerle 2005 öğretim programının felsefesi, öğrenme ve öğretme sürecinde öğrenci merkezli yöntem ve tekniklerin kullanmasına vurgu yapmakta ve geleneksel öğretme ortamını değiştirerek eğitim ortamlarına çeşitli yenilikler getirmektedir.

Yenilik, yeni olarak algılanan fikir, nesne ya da uygulamanın sistemin üyeleri arasında belli kanallar aracilığıla iletişimde bulunma süreci olarak tanımlanmaktadır. Her hangi bir nesne, fikir, teknik ya da uygulama eski dahi olsa kişi veya toplum tarafindan ilk kez algılanıyorsa bu bir yenilik olarak kabul edilir (Rogers, 2003).Yenilikleri benimsemek ve uygulamaya koymak genelde kolay olmamaktadır. Çünkü insanın doğasında yenilik ve değişmeye karşı bir 
tepki ve isteksizlik bulunmaktadır (Çınar vd., 2006; Yatağan 2014). Abrami, Poulsen ve Chambers'e (2004) göre eğitimsel yeniliklerin uygulanması çoğunlukla sınırlı düzeyde başarıya ulaşmaktadır. MEB'de yapılan yenilikleri bazı öğretmenler kendi öğretimiyle bütünleştirerek büyük bir coşkuyla uygularken bazıları yeni bir öğretim stratejisini hiç denememekte ya da başlangıçta çok az denedikten sonra geleneksel öğretim repertuarlarına geri dönmektedirler (Koç, 2015). Öğretmenlerdeki "En iyi yol bildiğin yoldur." anlayışı değişim ve yeniliğe karşı öğretmenlerin geleneksel eğitim anlayışında olduklarını da göstermektedir (Çınar vd., 2006; Yatağan 2014). Öğretmenlerin yenilikleri hayata geçirmediği bir ortamda eğitimsel gelişimden bahsetmek mümkün görünmemektedir (Bitkin, 2012). Aynı zamanda öğretmenler bir yeniliğin gerektirdiği becerileri kazanmadıkça ve yeniliği benimsemedikçe hiçbir yenilikten de beklenen başarı elde edilemeyecektir (Açıkgöz, 2002).

Eğitimsel yeniliklerde üç tür öğretmen davranış1 görülmektedir. Bunlar yeniliği denemeyi seven yenilikçiler, bekle gör tutumunu sergileyen orta ve geniş grup ve yeniliğe direnç gösteren sabit fikirlilerdir (Koç, 2015; Stevens, 2004). Yeniliği gerçekleştirmenin yolu yenilikçi olmaktan geçmekte (Naktiyok, 2007 ), yeniliklerin hayata geçirilmesinde yenilikçi kadrolar önemli bir faktör olarak değerlendirilmektedir (Durmuş, 2018). Yenilikçilik bireylerin yeniliklere verdikleri tepki olarak tanımlanmaktadır (Demiralay vd., 2016). Rogers'e (2003) göre yenilikçiler yeni fikirleri denemeye istekli ve risk alma eğiliminde olan bireylerdir. Öğretmenlerin yenilikçilik algılarına sahip olması, yeniliklere karşı tutumları, yetenekleri, yeni eğitim ürünleri ve eğitim teknolojileri oluşturmaya hazır olmaları eğitimin yenilikçi doğası açısından önemlidir (Erden ve Erden, 2020; Trapitsin vd., 2018). Çünkü bilimsel ve teknolojik gelişmeler, yeni müfredatlar, yeni öğrenme ve öğretme yöntemleri, bireyden beklenen beceriler, değişen öğrenci ve toplumun ihtiyaçları öğretmenlerin yenilikçi özelliklere sahip olmasını gerektirmektedir (Kocasaraç ve Karataş, 2017). Bu bağlamda MEB'de yenilikçi öğretmenlerin sayısının fazla olması getirilen yeniliklerin öğretmenler tarafından benimsenmesini kolaylaştırabilir. Aynı zamanda öğrenme öğretme sürecinde çeşitli yöntem ve tekniklerin kullanılmasını artırabilir.

Alanyazın incelendiğinde öğretmenlerin öğrenme öğretme sürecinde yalnızca bildikleri yöntem ve teknikleri kullandıkları, bunların daha çok öğretmen merkezli yöntem ve teknikler olduğu ve sayısının da çok az olduğu görülmektedir (Akpınar ve Gezer, 2010; Aliusta vd., 2015; Covill 2011; Çetin, 2017; Kayabaş1, 2012; İlter, 2014). Öğretmenler sınıfların kalabalık olmasını, okulların fiziki alt yapısının uygun olmamasını, öğrenci merkezli yöntem ve tekniklerin çok zaman almasını gerekçe göstererek geleneksel yaklaşıma uygun öğretim gerçekleştirdiklerini belirtmiş̧lerdir (Demirkan ve Saraçoğlu, 2016). Ancak Çetin (2017) yaptığı çalı̧̧mada öğrenci merkezli yöntem ve teknikler için uygun olan ortamlarda da öğretmenlerin geleneksel yönteme uygun öğretim 
gerçekleştirdiklerini vurgulamıştır. Öğretmenlerin geleneksel yaklaşımlardan vazgeçmemeleri, birçok ülkede büyüyen bir eğitim sorunu olarak ele alınmaktadır (Akpınar ve Gezer, 2010; Patrick, 2003). Öğretmenlerin geleneksel yaklaşıma bağlı kalması, yapılandırmacı yaklaşımın felsefesine uygun olarak öğrenci merkezli yöntem ve teknikleri kullanmaması, öğretmenlerin yenilikçi tutum sergilememeleri ile ilişkili olabilir. Öğretmenlerin desteklemediğgi değişim ve yeniliklerin uygulamada fazla başarılı olamayacağ 1 gerçeğinden hareketle (Akpınar ve Gezer, 2010; Bitkin, 2012; Çetin, 2017), eğitim yaklaşımlarında meydana gelen yeniliklerin uygulamaya geçirilmesinin öğretmenlerin sahip oldukları yenilikçilik anlayışıyla ilişkisi olup olmadığının belirlenmesi gerekmektedir. Bu yüzden bu araştırmada öğretmenlerin bireysel yenilikçilik düzeyleri ve öğrenme-öğretme sürecinde uyguladıkları öğrenci merkezli yöntem ve teknik arasındaki olası ilişki ortaya çıkartılmaya çalışılmıştır. Araştırmadan elde edilen verilerin yönetici, araştırmacı ve öğretmenlere rehberlik etmesi, ayrıca alanyazında konuyla ilgili eksikliğin giderilmesine katkı sunması beklenmektedir.

$\mathrm{Bu}$ araştırmanın amacı; öğretmenlerin bireysel yenilikçilik algı düzeyleri ile öğrenci merkezli öğretim yöntem ve teknikleri kullanmaya yönelik tutum düzeylerini belirleyerek bu iki değişken arasındaki olası ilişkiyi ortaya çıkarmaktır. Bu amaç doğrultusunda aşağıdaki sorula cevap aranmıştır.

1.Öğretmenlerin bireysel yenilikçilik algıları hangi düzeydedir?

2.Öğretmenlerin öğrenci merkezli yöntem ve teknikleri kullanmaya ilişkin tutumu hangi düzeydedir?

3.Öğretmenlerin bireysel yenilikçilik algıları ile öğrenci merkezli yöntem ve teknikleri kullanmaya ilişkin tutumları arasında anlamlı bir ilişki var mıdır?

4.Öğretmenlerin bireysel yenilikçilik algı düzeyleri, öğrenci merkezli yöntem ve teknikleri kullanmaya ilişkin tutumlarının anlamlı bir yordayıcısı mıdır?

\section{YÖNTEM}

\section{Araştırmanın Modeli}

$\mathrm{Bu}$ araştırmada öğretmenlerin bireysel yenilikçilik algıları ile öğrenci merkezli yöntem ve teknikleri kullanmaya ilişskin tutumları arasındaki ilişkiyi incelenmek amaçlandığından nicel araştırmalardan ilişkisel tarama modeli kullanılmıştır. İlişsisel tarama modeli genel tarama modelleri içerisinde olup iki ya da daha fazla değişken arasındaki değişimin varlığı ya da derecesini belirlemede kullanılan araştırma modelidir (Büyüköztürk vd., 2014; Karasar, 2005). İlişkisel tarama modelinde değişkenlerden ölçme araçları kullanılarak elde 
edilen veriler bazı istatistiksel yöntemlerle analiz edilerek ve değişkenler arasındaki olası ilişki sayısal olarak ifade edilir (Creswell, 2014). İlişkisel tarama modelinde bir değişkendeki durumun bilinmesi diğer değişkenin durumunun kestirilmesine yardımcı olabilir (Karasar, 2005).

\section{Evren ve Örneklem}

Araştırmanın evrenini, 2018-2019 eğitim-öğretim yılında Kahramanmaraş il merkezinde görev yapan öğretmenler oluştururken araştırmanın örneklemini ise bu evrenden tabakalı örnekleme yoluyla seçilen farklı okul türlerinde görev yapan 212 kadın ve 236 erkek olmak üzere toplam 448 öğretmen oluşturmuştur. Tabakalı örneklem evrenin homojen olmadığ 1 durumlarda alt gruplar ana kütleden ayrilır daha sonra alt gruplardan rassal örnekleme ile veri toplanır (Karagöz, 2017; Yıldırım ve Şimşek, 2011 ). Örneklem seçiminde öncelikle öğretmenlerin görev yaptığı okul türleri, ana sınıfi, ilkokul, ortaokul ve lise düzeyinde gruplandırılmıştır. Bu gruplardan tesadüfi olarak okullar belirlenmiş ve bu okullarda görev yapan öğretmenlere internet aracıllğ katılımları sağlanmıştır. Araştırmaya katılan öğretmenlerin 54' ü okul öncesinde (\%12), 180’ni ilkokulda (\%40), 110’u ortaokulda (\%25), 104'ü ise lisede (\%23) görev yapmaktadır. Araştırmaya katılan öğretmenlerin 57'si 0-5 yıl (\%13), 88'u 6-10 y1l (\%20), 106's1 11-15 y1l (\%24), 112'si 16-20 yıl (\%25), 85'i ise 21 y1l ve üzeri (\%19)öğretmenlik deneyime sahiptirler.

\section{Veri Toplama Araçları ve Süreci}

Öğretmenlerin bireysel yenilikçilik alg1 düzeylerini ve öğrenci merkezli yöntem ve teknikleri kullanmaya ilişkin tutum düzeylerini belirlemede veri toplama araçları olarak "Bireysel Yenilikçilik Ölçeği (BYÖ)" ve "Öğrenci Merkezli Öğretim Yöntem ve Tekniklerini Kullanmaya Yönelik Tutum Ölçeği (ÖMÖYTKYTÖ)" kullanılmıştır. Ayrıca araştırmaya katılan öğretmenlerin demografik özelliklerini belirlemek için araştırmacı tarafindan geliştirilen "Kişisel Bilgi Formu" kullanılmıştır. Bunun yanında ölçekleri geliştiren ve uyarlayan araştırmacılardan ölçeği araştırmada kullanmak için gerekli izinler alınmıştır.

\section{Bireysel Yenilikçilik Ölçeği}

Hurt, Joseph ve Cook (1977) tarafından geliştirilen ölçek Kıliçer ve Odabaşı (2010) tarafindan Türkçeye uyarlanmıştır. Kılıç (2015) ise bazı biçimsel düzenleme yaparak ölçeği öğretmenlere uygulamış geçerlik ve güvenirlik çalışması yapmıştır. 20 madden oluşan ölçek değişime direnç ( 8 madde), fikir önderliği (5 madde), deneyime açıklık (5 madde) ve risk alma ( 2 madde) olmak üzere dört boyuttan oluşmaktadır. Ölçeğin güvenirlik katsayıları ise sırasıyla değişime direnç boyutu için .82 fikir önderliği boyutu için .77 deneyime açılık 
boyutu için .80 ve risk alma boyutu için .61 ve ölçeğin geneli için ise .87 olarak hesaplanmıştır. Bu araştırmada yapılan geçerlik ve güvenirlik çalışmasında ise ölçeğin güvenirlik katsayıları direnç boyutu için .88 fikir önderliği boyutu için . 88 deneyime açıklık boyutu için .84 risk alma boyutu için .77 ve ölçeğin geneli için ise .88 olarak hesaplanmıştır. Ölçek maddeleri kesinlikle katılıyorum (5), katılıyorum (4), ortadayım (3), katılmıyorum (2), kesinlikle katılmıyorum (1)şeklinde beşli likert olarak derecelendirilmiştir. Bireysel yenilikçilik ölçeğinin değişime direnç boyutunu oluşturan tüm maddeler $(4,6,7,10,13,15,17$. ve 20) olumsuz maddeler olduğu için tersten kodlama yapılarak analiz edilmiştir.

\section{Öğrenci Merkezli Öğretim Yöntem ve Tekniklerini Kullanmaya Yönelik Tutum Ölçeği}

Öğretmenlerin öğrenci merkezli yöntem ve tekniklerini kullanmaya yönelik tutumlarını ölçebilmek için Koç (2014) tarafından geliştirilen 27 maddelik ölçek kullanılmıştır. Ölçek değer verme, direnç gösterme, olumlu etkiler ve maliyet inancı olmak üzere dört boyuttan oluşmaktadır. Ölçeğin güvenirlik katsayıları ölçeği geliştiren araştırmacı tarafından değer verme için .94, direnç gösterme için .89 , olumlu etkiler için .90 , maliyet inanc1 için .84 olarak ölçeğin tamamı için .93 olarak hesaplanmıştır. Bu araştırmada yapılan güvenirlik çalışmasında ölçeğin güvenirlik katsayıları, değer verme için .95 , direnç gösterme için. 86 , olumlu etkiler için. 94, maliyet inancı için .76 ölçeğin tamamı için. 94 olarak hesaplanmıştır. Ölçek maddeleri kesinlikle katılmıyorum (1), katılmıyorum (2), kararsızım (3), katılıyorum (4), tamamen katılıyorum (5) şeklinde beşli likert olarak derecelendirilmiştir. Öğrenci merkezli yöntem ve tekniklerini kullanmaya ilişkin tutum ölçeğinin direnç gösterme alt boyutundaki tüm maddeler $(2,4,6,8$, $10,12,14)$ ve maliyet inanc1 alt boyutundaki tüm maddeler $(20,22,24,26)$ olumsuz yargı içerdikleri için tersten kodlama yapılarak analiz edilmiştir.

$\mathrm{Bu}$ araştırmada veriler Web Tabanlı Anket Hazırlama yazılımı kullanarak online toplanmıştır. Online veri toplama kolay ulaşılabilirlik, ekonomiklik ve istekli olanların katılım göstermesi gibi avantajlarından dolayı araştırmacılar tarafından son yıllarda yaygın olarak kullanılan bir yöntemdir (Çeliköz ve Erişen, 2017). Bu araştırmada ölçek maddelerinin Web tabanlı anket hazırlama yazılım programına aktarılması; uygulanmasını, veri toplanmasını daha ekonomik ve pratik hale getirmiştir. Web tabanlı anket hazırlama yazılım programı sayesinde ölçek katılımcılara internet bağlantısı olan telefon ya da bilgisayar gibi cihazlarla hızlı bir şekilde ulaştırılmakta, gönüllü olan katılımcılar ölçek maddelerini kolay bir şekilde istediği her yerde doldurabilmektedirler. Ayrıca kâğıt üzerinde her hangi bir işlem yapılmadığından kağıt üzerindeki verilerin bilgisayar ortamına taşınması gibi bir problemde olmamaktadır (Özüsağlam vd., 2009). Bu araştırmada internet üzerinden hizmet veren Web tabanlı anket hazırlama sitelerinden güvenilir ve işlevsel olduğu düşünülen birine üye olunmuştur. Daha 
sonra sisteme ölçek maddeleri yüklenerek ölçme aracı internet ortamına aktarılmıştır. Ölçme aracı internet ortamda öğretmenlere gönderilerek doldurmaları istenmiştir. Öğretmenlerden gelen dönütlerin örneklem için yeteri sayıya ulaştığı düşünüldüğünde sistem kapatılmıştır. Veri toplama süreci yaklaşık 15 gün sürmüş, süreç sonunda veriler SPSS programına aktarılmıştır.

\section{Verilerin Analizi}

Araştırmada verilerin analizinde SPSS 21 istatistik paket programı kullanılmıştır. Öğretmenlerin bireysel yenilikçilik alg1 düzeylerini ve öğrenci merkezli yöntem ve teknikleri kullanmaya ilişkin tutum düzeylerini belirlemek adına frekans, aritmetik ortalama ve standart sapmaları değerleri hesaplanmıştır. Ayrıca öğrenci merkezli yöntem ve tekniklerini kullanmaya ilişkin tutum düzeyi ile bireysel yenilikçilik düzeyleri arasındaki olası anlamlı ilişkiyi ortaya çıkarmak için Pearson korelasyon katsayısı hesaplanmıştır. Bağımsız değişkenlerin bağımlı değişkeni anlamlı olarak yordayıp yordamadığını belirleyebilmek için de çoklu regresyon analizi yapılmıştır. Regresyon analizi, bağımlı değişken (yordanan) ile bağımsız değişken (yordayıcı değişken) arasındaki ilişkiyi matematiksel bir bağıntıyla açıklamaya çalışan bir analiz türüdür (Çokluk, Şekercioğlu ve Büyüköztürk, 2012). Bu araştırmada bağımsız değişken öğretmenlerin bireysel yenilikçileri iken bağımlı değişken öğretmenlerin öğrenci merkezli yöntem ve tekniklerini kullanmaya ilişkin tutumlarıdır. Çoklu regresyon analizlerinin uygulanabilmesi için ise bağımlı ve bağımsız değişkenlerin normal dağılım göstermesi gerekmektedir (Çokluk, vd., 2012). Ölçekteki verilerin normal dağılım gösterip göstermediği test etmek için histogram ve Q-Q plot grafiğini bakılmış ve veri sayısının 30'u geçmesinden de hareketle verilerin normal dağıldığı varsayılmıştır. Regresyon analizlerinin yorumlanmasında standartlaştırılmış Beta $(\beta)$ katsayıları ve bunların anlamlılığı için t-testi sonuçlarına bakılmıştır. Bulguların istatistiksel olarak analiz edilmesinde '.05' anlamlılık düzeyi kriter olarak ele alınmıştır.

Her iki ölçeğin ortalamalarının değerlendirme aralığ 1 (5-1)/5=0.80 belirlenmiştir. (Kan, 2009; 407). BYÖ ve ÖMÖYTKYTÖ yer alan maddenin aritmetik ortalama puanları $1.00-1.80$ aras1 "Kesinlikle Katılmıyorum", 1.81 2.60 aras1 "Katılmıyorum", $2.61-3.40$ aras " "Ortadayım/Kararsızım", 3.41 - 4.20 arası "Kat1liyorum", $4.21-5.00$ arası "Kesinlikle Kat1liyorum" şeklindeki puan aralıkları dikkate alınarak değerlendirilmiş öğretmenlerin bireysel yenilikçilik algı düzeyleri ve öğrenci merkezli yöntem ve teknik kullanmaya ilişkin tutum düzeyleri belirlenmiştir. 


\section{BULGULAR}

Araştırmanın bu bölümünde araştırmanın cevap aradığı sorulara ilişkin ölçeklerden elde edilen bulgular, araştırmanın alt problemleri dikkate alınarak sırasıyla tablolar şeklinde verilmiştir.

\section{Öğretmenlerin Bireysel Yenilikçilik Algılarına İlişkin Bulgular}

Araştırmanın birinci alt problemi olan öğretmenlerin bireysel yenilikçilik algı düzeylerin belirlemek için kullanılan ölçeğin geneli ve alt boyutlarıyla ilgili betimsel istatistik Tablo 1'de verilmiştir.

Tablo 1. BYÖ Puanlarına İlişkin Aritmetik Ortalama, Standart Sapma ve Aralık Değerleri

\begin{tabular}{llcll}
\hline Değişken & $\mathbf{N}$ & $\overline{\mathrm{X}}$ & $\mathbf{S}$ & Aralık \\
\hline Değişime direnç & 448 & 3.58 & .793 & Katılıyorum \\
Fikir önderliği & 448 & 4.12 & .738 & Katılıyorum \\
Deneyime açıklık & 448 & 3.77 & .723 & Katılıyorum \\
Risk alma & 448 & 3.63 & .866 & Katılıyorum \\
BYÖ Toplam & $\mathbf{4 4 8}$ & $\mathbf{3 . 7 7}$ & $\mathbf{. 5 3 7}$ & Katılıyorum \\
\hline
\end{tabular}

Tablo 1 incelendiğinde öğretmenlerin bireysel yenilikçilik ölçeği alt boyutları aritmetik ortalamaları puanları yüksekten düşüğe doğru fikir önderliği 4.12, deneyime açıklık 3.77, değişime direnç 3.58 , risk alma 3.63 olduğu görülmektedir. Ölçeğin genelinin aritmetik ortalaması ise 3.77 'dir. Öğretmen görüşlerinden elde edilen ortalama puanlar ölçeğin alt boyutlarında ve genelinde katılıyorum aralığında yer almaktadır.

Öğretmenlerin Öğrenci Merkezli Öğretim Yöntem ve Tekniklerini Kullanmaya Yönelik Tutumlarına İlişkin Bulgular

Araştırmanın ikinci alt problemi olan öğretmenlerin öğrenci merkezli yöntem ve tekniklerini kullanmaya ilişkin tutum düzeylerin belirlemek için kullanılan ölçeğin geneli ve alt boyutlarıla ilgili betimsel istatistik Tablo 2'de verilmiştir.

Tablo 2. ÖMÖYTKYTÖ Puanlarına İlişkin Aritmetik Ortalama, Standart Sapma ve Aralık Değerleri

\begin{tabular}{lccll}
\hline Değişken & $\mathbf{N}$ & $\overline{\mathrm{X}}$ & $\mathbf{S}$ & Aralık \\
\hline Değer verme & 448 & 3.94 & .781 & Katılıyorum \\
Direnç gösterme & 448 & 3.61 & .821 & Katıllyorum \\
Olumlu etkiler & 448 & 4.03 & .830 & Katılıyorum
\end{tabular}




\begin{tabular}{lrlll} 
Maliyet inancı & 448 & 3.08 & .845 & Kararsızım \\
ÖMÖYTKYTÖ Toplam & $\mathbf{4 4 8}$ & $\mathbf{3 . 7 4}$ & $\mathbf{. 6 2 0}$ & Katılıyorum \\
\hline
\end{tabular}

Tablo 2 incelendiğinde öğrenci merkezli yöntem ve teknik kullanmaya yönelik tutum ölçeğinin alt boyutlarının aritmetik ortalamaları ve katılım düzeyi yüksekten düşüğe doğru olumlu etkiler 4.03 ortalamayla katılıyorum düzeyinde, değer verme 3,94 ortalamayla katılıyorum düzeyinde, direnç gösterme 3,61 ortalamayla katılmıyorum düzeyinde, maliyet inanc1, 3,08 ortalamayla kararsızım düzeyinde, olduğu görülmektedir. Öğretmenler ölçeğin genelinde ortalama puanları 3, 74 ortalamayla katılıyorum aralığında görüş bildirmiş̧lerdir. Öğretmen görüşlerinden elde edilen ortalama puanlar ölçeğin maliyet inancı alt boyutu dışındaki alt boyutlarında ve genelinde katılıyorum aralığında yer almaktadır.

\section{Öğretmenlerin Bireysel Yenilikçilik Algıları İle Öğrenci Merkezli Yöntem ve Teknik Kullanmaya Yönelik Tutum Düzeyleri Arasındaki İlişskiye Ait Bulgular}

Araştırmanın üçüncü alt problemi öğretmenlerin bireysel yenilikçilik alg1 düzeyleri ile öğrenci merkezli yöntem ve teknik kullanmaya yönelik tutum düzeyleri arasında anlamlı bir ilişki olup olmadığını belirlemek için yapılan Pearson-Moment Çarpımı Korelâsyonun sonucu elde edilen bulgular Tablo 3'de verilmiştir.

Tablo 3. BYÖ ile ÖMÖYTKYTÖ Puanları Arasındaki İlişkiyi Gösteren Pearson Momentler Çarpım Korelasyonu Sonuçları

\begin{tabular}{|c|c|c|c|c|c|c|c|c|c|}
\hline Değişkenler & 1 & 2 & 3 & 4 & 5 & 6 & 7 & 8 & 910 \\
\hline BYÖ Toplam & 1 & & & & & & & & \\
\hline Değişime Direnç & $.664^{* *}$ & & & & & & & & \\
\hline Fikir Önderliği & $.795^{* *}$ & ${ }^{*} .191^{* *}$ & & & & & & & \\
\hline Deneyime Açıklık & $.710^{* *}$ & .025 & $.710^{*}$ & & & & & & \\
\hline Risk Alma & $.595^{* *}$ & .057 & $.596^{*}$ & $* .580^{* *}$ & & & & & \\
\hline ÖМÖYTKYТÖ Тор & $.644^{* *}$ & $.433^{* *}$ & ${ }^{*} .538^{*}$ & ${ }^{*} .437^{* *}$ & ${ }^{* *} .353^{* *}$ & & & & \\
\hline Değer Verme & $.571^{* *}$ & ${ }^{*} .161^{* *}$ & *634* & ${ }^{*} .551^{* *}$ & ${ }^{* *} .449^{*}$ & ${ }^{*} .868^{* *}$ & & & \\
\hline Direnç Gösterme & $.491^{* *}$ & ${ }^{*} .646^{* *}$ & ${ }^{*} .187^{*}$ & *.088 & $.100^{*}$ & $.730^{* *}$ & & ${ }^{*} 1$ & \\
\hline Olumlu Etkiler & $.526^{* *}$ & ${ }^{*} .178^{* *}$ & ${ }^{*} .570^{*}$ & ${ }^{*} .487^{* *}$ & **.381* & ${ }^{*} .855^{* *}$ & ${ }^{*} .902^{* *}$ & & *1 1 \\
\hline Maliyet İnanc1 & $.261^{* *}$ & $.410^{* *}$ & .040 & .024 & -.019 & $.447^{* *}$ & *.062 & $.574^{* *}$ & *.0651 \\
\hline
\end{tabular}

Bireysel yenlikçilik ölçeğinin alt boyutları arasında ilişki düzeyi yüksekten düşüğe doğru sırasıyla; deneyime açıklık ile fikir önderliği boyutları $(\mathrm{r}=.710)$, fikir önderliği ile risk alma boyutları $(\mathrm{r}=.596)$, risk alma ile deneyime açıklık 
boyutları ( $\mathrm{r}=.580)$, değişime direnç ile fikir önderliği boyutları ( $\mathrm{r}=.191)$, değişime direç ile risk alma boyutları $(\mathrm{r}=.057)$, değişime direnç ile deneyime açık olma boyutları $(\mathrm{r}=.025)$ arasındadır. ÖMÖYTKYTÖ alt boyutları arasında ilişki düzeyi yüksekten düşüğe doğru sırasıyla; değer verme ile olumlu etkiler boyutları $(\mathrm{r}=902)$, direnç gösterme ile maliyet inancı boyutları $(\mathrm{r}=.574)$, direnç gösterme ile olumlu etkiler boyutları $(\mathrm{r}=.361)$, değer verme ile direnç gösterme boyutları $(\mathrm{r}=.351)$, olumlu etkiler ile maliyet inanc1 boyutları $(\mathrm{r}=.65)$, değer verme ile maliyet inancı arasindadır $(\mathrm{r}=.062)$.

BYÖ ile ÖMÖYTKYTÖ arasında korelasyon incelendiğinde ise ölçeklerin geneline göre iki değişken arasında pozitif yönde orta düzeyde $(r=.644)$ ilişki olduğu görülmektedir. Bu durum öğretmenlerin bireysel yenilikçilik düzeyleri yükseldiğinde öğrenci merkezli yöntem ve teknikleri kullanımına ilişkin tutumlarının da artacağı şeklinde yorumlanabilir. İki ölçeğin alt boyutları göre korelasyonlar incelendiğinde en yüksek ilişki fikir önderliği ile değer verme arasında $(\mathrm{r}=.634)$ iken en düşük ilişki ise risk alma ile maliyet inancı alt boyutları $(\mathrm{r}=-.019)$ arasindadır.

\section{Öğretmenlerin Bireysel Yenilikçiliğinin Öğrenci Merkezli Yöntem ve Teknik Kullanmaya Yönelik Tutumlarını Yordamasına İlişsin Bulgular}

Araştırmanın dördüncü alt problemi öğretmenlerin bireysel yenilikçiliğinin öğretmenlerin öğrenci merkezli yöntem ve tekniklerini kullanmaya ilişkin tutumlarının anlamlı bir yordayıcısı olup olmadığını ortaya çıkarmaktır. Bu kapsamda yapılan regresyon analizi sonuçları Tablo 4'de sunulmuştur.

Tablo 4. Öğrenci Merkezli Öğretim Yöntem ve Tekniklerini Kullanmaya Yönelik Tutum Ölçeği Toplan Puanı ve Yordayıcı Değişkenlere İlişkin Çoklu Regresyon Analizi Sonuçları

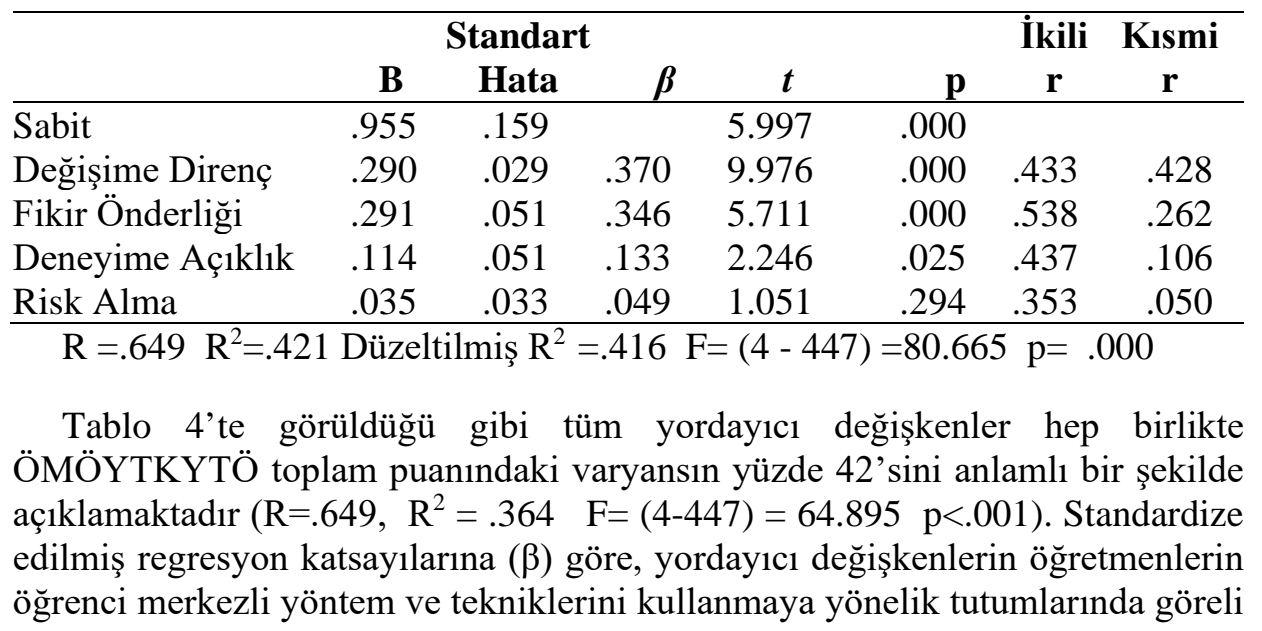


önem sırası; değişime direnç (.370), fikir önderliği (.346), deneyime açıklık (.133) ve risk alma (.049) şeklindedir. Regresyon katsayılarının anlamlılı̆̆ına ilişkin $\mathrm{t}$ testi sonuçları incelendiğinde, değişime direnç, fikir önderliği ve deneyime açıklığın öğrenci merkezli yöntem ve teknikleri kullanmaya yönelik tutum puanları üzerinde anlamlı yordayıcılar olduğu, risk almanın ise anlamlı bir yordayıcı olmadığı görülmektedir. Elde edilen regresyon analizi sonuçlarına göre öğrenci merkezli öğretim yöntem ve tekniklerini kullanmaya yönelik tutumun yordanmasına ilişkin regresyon eşitliği (matematiksel model) ise şu şekildedir:

Öğrenci merkezli öğretim yöntem ve tekniklerini kullanmaya yönelik tutum = $.955+.290 *$ değişime direnç $+.291 *$ fikir önderliği $+.114 *$ deneyime açıklık + $.035 *$ risk alma

\section{SONUÇ VE TARTIŞMA}

$\mathrm{Bu}$ araştırmanın sonucunda öğretmenlerin bireysel yenilikçilik algı düzeylerin "katıllyorum" düzeyinde olduğu görülmektedir. Ölçeğin alt boyutunda ve toplamında öğretmenlerin katılıyorum düzeyde görüş bildirmesini alanyazında yapılan çalışmalar desteklemektedir (Akın Kösterelioğlu ve Demir, 2014; Kayasandık, 2017; Kılıç, 2015; Kılıç ve Ayvaz Tuncel, 2014; Saraç, 2019). Bu araştırmanın sonucundan farklı olarak bazı araştırmalarda öğretmenler "ortadayım" şeklinde görüş bildirmişlerdir (Aslan ve Kesik, 2018; Başaran ve Keleş, 2015; Kayabaşı ve Özerbaş, 2019; Yenice ve Tunç, 2019). Bu araştırmada ve araştırma sonucunu destekleyen alanyazındaki araştırmalarda öğretmenlerin kesinlikle katılıyorum diye görüş bildirmemesi öğretmenlerin; yeniliklere karşı ihtiyatlı ve temkinli davrandıkları, yenilikleri benimseme sürecinde yavaş hareket ettikleri, alışkanlıklarından vazgeçmede güçlük çektikleri anlamına gelebilir. Yenilikleri uygulanmada bireysel düzeyde yenilikçilik önem arz etmektedir. Yeni ürünleri, hizmetleri ve yöntemleri denemeye istekli bireyler yenilikleri yönlendirme potansiyeline sahiptirler (Elçi, 2012; Sansom, 2017). Ayrıca bireylerin deneyime açık olmaları dişsal bir uyarıcıya ihtiyaç duymadan içsel motivasyonla yeni fikirler ve ürünler ortaya koymasını kolaylaştırmaktadır (Gürkan ve Demiralay, 2017). Bireysel yenilikçi bireyler farklı yaşantılarla kendilerini geliştirmekte, yeni bilgilerini önceki bilgilerini bütünleştirerek kullanmaktadırlar (Başaran ve Keleş, 2015; Demiralay vd., 2016). Bireysel yenilikçi bireylerin özellikleri ve öğretmenlerin görevleri dikkate alındığında öğretmenlerin bireysel yenilikçiliklerinin yüksek düzeyde olması ülkelerin eğitim öğretiminin niteliği için önemlidir (Sansom, 2017; Trapitsin vd., 2018). Diğer taraftan Kocasaraç ve Karataş (2017) yaptıkları çalışmada öğretmenlerin yenilikçilik kavramına yükledikleri anlamı teknolojiyi kullanma, yeniliklere uyum sağlama, günceli takip etme, kendini geliştirme, faklı öğretim yöntemlerini kullanma ve öğrencileri geleceğe hazırlama şeklinde belirtmiştir (Kocasaraç ve Karataş, 2017). Bu araştırmada öğretmenlerin bireysel yenilikçiliklerini 
katıllyorum düzeyinde belirtmesi Kocasaraç ve Karataş'ın (2017) belirttiği yenilikçilik algısına göre öğretmenlerin kendilerini geliştirmeleri gerektiği anlamına gelebilir.

$\mathrm{Bu}$ araştırmanın sonucunda öğretmenlerin öğrenci merkezli yöntem ve teknikleri kullanmaya yönelik tutumlarının "katılıyorum" düzeyinde olduğu görülmektedir. Araştırmanın bu sonucu öğretmenlerin öğrenci merkezli yöntem ve teknikleri kullanmaya çok da istekli olmadıklarını göstermektedir. Alanyazında yapılan çalışmalarda öğretmenlerin genellikle öğretmen merkezli geleneksel yöntem ve teknikleri kullanması (Akpınar ve Gezer, 2010; Aliusta vd, 2015; Covill 2011; Çetin, 2017; Kayabaş1, 2012; İlter, 2014) araştırmanın bu sonucunu destekler niteliktedir. Bu da Türkiye'de yapılandırmacı yaklaşımla hazırlanan öğretim programların felsefesine uygun eğitim verilmediği anlamına gelebilir. Öğretmenin öğrenci merkezli yöntem ve teknikleri seçimini etkileyecek pek çok faktör bulunmaktadır. Bunlar; öğretmenlerin öğrenci merkezli yöntem ve teknik hakkında bilgi sahibi olması, yöntem ve tekniği kullanmaya yatkın olması, fiziki donanımlar, yeterli zaman, maliyet, sınıfların kalabalık olması, konunun içeriği, öğrencinin hazırbulunuşluğu, kazandırmak istenilen davranışın niteliği şeklindedir (Aksu ve Doğan, 2015). Ayrıca öğretmenlerin öğrenci merkezli yöntem ve teknikleri kullanmalarına öğretmenlerin deneyime açıklığı, tutumu, başarılı olacağına inanması, maliyet, değer verme, risk alma, fikir önderliği değişime direnç gibi faktörler etki etmiş olabilir.

$\mathrm{Bu}$ araştırmada öğretmenlerin bireysel yenilikçilik algı düzeyleri ile öğrenci merkezli yöntem ve teknik kullanmaya yönelik tutum düzeyleri arasında anlamlı bir ilişki olduğu tespit edilmiştir. Öğretmenlerin bireysel yenilikçiliği, öğrenci merkezli yöntem ve teknikleri kullanmaya yönelik tutumlarını anlamlı bir şekilde yordamakta ve toplam puan varyansının yüzde 42 'sini açıklamaktadır. Bireysel yenilikçilik ile öğrenci merkezli yöntem ve teknik kullanmaya yönelik tutumların alt boyutundaki bazı değişkenlerin bireydeki benzer özellikleri ortaya çıkarması bu iki ölçeğin puanları arasında olumlu ilişkinin çıkmasına neden olmuş olabilir. Alanyazın incelendiğinde bireysel yenilikçilikle; öğretmen liderliği (Akın Kösterelioğlu ve Demir, 2014), çevrimiçi öğrenmeye hazırbulunuşluk (Demiralay vd. 2016), eğitim araştırmalarına yönelik tutum (Akçöldekin, 2017), öğrenmeye ilişkin tutum düzeyi (Adıgüzel vd., 2014), bilgi edinme becerileri (Bitkin, 2012), teknoloji tutum düzeyi (Örün vd., 2015) arasında olumlu yönde pozitif ilişki olduğu görülmektedir. Ayrıca Erden ve Erden (2020) yaptı̆̆ 1 çalışmada öğretmen adaylarının sosyal girişimcilik özellikleri ile bireysel yenilikçilik özellikleri arasında güçlü bir ilişkinin olduğunu bulmuştur. $\mathrm{Bu}$ araştırma ile alanyazındaki diğer araştırmaların dikkat çekici ortak yönlerinin değişim olduğu söylenebilir. Sonuç olarak değişim ve gelişim bireysel yenilikçilikle ilişkilendirilebilir. Bu araştırmanın bulgularından elde edilen araştırmanın sonucuna göre aşağıdaki öneriler getirilmiştir. 
1. Bu araştırmanın bulgularına göre öğretmenlerin bireysel yenilikçiliklerinin "katıllyorum" düzeyinde olduğu tespit edilmiştir. Öğretmenlerin bireysel yenilikçiliklerini daha da artırarak "kesinlikle katılıyorum" düzeyine çıkaracak kurum içi ve kurum dışı etkinlikler yapılabilir.

2. $\mathrm{Bu}$ araştırmanın bulgularına göre öğrenci merkezli yöntem ve teknikleri kullanmaya yönelik tutumları algı düzeylerinin "katılıyorum" düzeyinde olduğu tespit edilmiştir. Öğretmenlerin öğrenci merkezli yöntem ve teknikleri kullanmaya yönelik tutumları algı düzeylerinin artırarak "kesinlikle katılıyorum" düzeyine çıkaracak kurum içi ve kurum dışı etkinlikler yapılabilir.

3. $\mathrm{Bu}$ araştırmanın bulgularına göre yenilikçilik alg1 düzeyleri ile öğrenci merkezli yöntem ve teknik kullanmaya yönelik tutum düzeyleri arasında anlamlı orta düzeyde bir ilişki olduğu tespit edilmiştir. Öğretmenlerin bireysel yenilikçilik algı düzeyleri ile artırılarak sınıflarda kullandıkları öğrenci merkezli yöntem ve tekniklerin çeşidi ve sayısı artırılabilir.

4. Öğretmenlerin her iki değişken için de katılıyorum düzeyinde görüş bildirmelerinin nedenleri nitel bir araştırma ile ortaya konabilir.

5. Öğretmenlerin bireysel yenilikçilik girişimleri desteklenebilir.

6. Nitel ve nicel araştırmalarla öğretmenlerin bireysel yenilikçilikleri önündeki engeller belirlenerek bu engellerin kaldırılması için araştırmalar yapilabilir.

7. Nitel ve nicel araştırmalarla öğretmenlerin bireysel yenilikçiliklerini geliştirecek faktörler belirlenerek öğretmelerin bu özellikleri kazanması sağlanabilir.

$\mathrm{Bu}$ araştırma 2019-2020 eğitim öğretim yılı Kahramanmaraş’ta görev yapan 448 öğretmenden BYÖ ve ÖMÖYTKYTÖ'den elde edilen verilerle sınırlıdır.

\section{KAYNAKÇA}

Abrami, Philip C.; Poulsen, Catherina ve Chambers, Bette (2004). "Teacher Motivation To İmplement An Educational İnnovation: Factors Differentiating Users and Non-Users of Cooperative Learning” Educational Psychology, Vol. 24, No:2, pp. 201-216.

Açıkgöz, Kamile Ün (2002). Aktif Öğrenme. İzmir: Kanyılmaz Matbaası.

Adigüzel, Abdullah; Kaya, Ahmet; Balay, Refik ve Göçen, Ahmet (2014).

"Öğretmen Adaylarının Bireysel Yenilikçilik Özellikleri İle 
Öğrenmeye İlişkin Tutum Düzeyleri.” Milli Eğitim. Cilt. 204, ss. 135154

Akçöltekin, Alptürk (2017). “Lise Öğretmenlerinin Bireysel Yenilikçilik Algıları ile Eğitim Araştırmalarına Yönelik Tutumları Arasındaki İlişkinin İncelenmesi." Eğitim Kuram ve Uygulama Araştırmaları Dergisi, Cilt. 03, No: 01, ss. 23-37.

Akın Kösterelioğlu, Meltem ve Demir, Fatih (2014). "Öğretmenlerin Bireysel Yenilikçilik Düzeyinin Öğretmen Liderliğine Etkisi.” The Journal of Academic Social Science Studies, Cilt. 26, ss. 247-256., Doi: 10.9761/JASSS2271

Akpınar, Burhan ve Gezer, Burcu (2010). “Öğrenen Merkezli Yeni Eğitim Yaklaşımlarının Öğrenme-Öğretme Sürecine Yansımalar.” Dicle Üniversitesi Ziya Gökalp Eğitim Fakültesi Dergisi, Cilt. 14, ss. 1-12.

Aksu, Gökhan ve Doğan, Nuri (2015). “Öğretim Yöntem ve Tekniklerinin Öğrenci Görüşlerine Göre İkili Karşılaştırma Yöntemiyle Ölçeklenmesi." Journal of Measurement and Evaluation in Education and Psychology , Vol. 6, No:2, ss. 195-206. DOI: 10.21031/epod.87629

Aliusta Gülen, Onurkan-Özer Bekir - Kan, Adnan (2015). "Öğrenci Merkezli Öğretim Stratejilerinin Kuzey Kıbrıs'taki Okullarda Uygulanması.” Eğitim ve Bilim, Cilt. 40, Sayı:181, ss. 77-91.

Arkhipova, Marina Yu and Kuchmaeva, Oksana V. (2018). "Social demand of Russians for innovation (according to a sample survey).” Economic and Social Changes: Facts, Trends, Forecast, Vol. 11. No:2, 69-83, doi: 10.15838/esc.2018.2.56.5

Aslan, Hüseyin ve Kesik, Fatma (2018). "Lise Öğretmenlerinin Bireysel Yenilikçilik Özelliklerinin Çeşitli Değişkenlere Göre İncelenmesi”. Journal of Human Sciences, Vol. 15. No: 4, ss. 2215-2228

Bay, Erdal (2008). Öğretmen Eğitiminde Yapılandırmacı Program Uygulamalarının Etkinliğinin Değerlendirilmesi. Yayınlanmamış Doktora Tezi, Atatürk Üniversitesi Sosyal Bilimler Enstitüsü, Erzurum

Bayır, Eylem (2008). Fen Müfredatlarındaki Yeni Yönelimler Işı̆ı̆ında Öğretmen Eğitim: Sorgulayıcı-Araştırma Odaklı Kimya Öğretimi, Yayınlanmamış Doktora Tezi Gazi Üniversitesi Eğitim Bilimleri Enstitüsü, Ankara 
Bitkin, Ayşe (2012). Öğretmen Adaylarının Bireysel Yenilikçilik Düzeyleri İle Bilgi Edinme Becerileri Arasındaki İlişki, Yayınlanmamış Yüksek Lisans Tezi, Harran Üniversitesi Sosyal Bilimler Enstitüsü Eğitim Bilimleri Anabilim Dalı, Şanlıurfa

Büyüköztürk, Şener; Kıllı̧ Çakmak, Ebru; Akgün Özcan, Erkan; Karadeniz, Şirin ve Demirel, Funda (2014). Bilimsel Araştırma Yöntemleri (17. Bask1). Pegem Yayınları, Ankara

Caena, Francesca (2014). "Teacher Competence Frameworks in Europe: Policy-as-discourse and policy-as-practice”, European Journal of Education, Vol. 49, No:3, pp. 311-331. DOI: 10.1111/ejed.12088

Covill, Amy E. (2011). "College Students Perceptions of the Traditional Lecture Method.” College Student Journal, Vol. 45 No:1, ss. 2-15.

Creswell, John W. (2014). Research Design Qualitatitive, Quantitative, and Mixed Methods Approaches. Sage Publications, London

Çeliköz, Mine ve Erişen, Yavuz (2017). EPÖ Alanında Görev Yapan Eğitim Bilimcilerin Yapılandırmacılıkla İlgili Görüşleri: Bir Karma Yöntem Araştırması. Eğitim ve Öğretim Araştırmaları Dergisi, Cilt. 6, Sayı: 2, ss. 286-304.

Çetin, Abdullah (2017). Özel Dershanelerden Resmi Okullara Atanan İlköğretim Fen Bilimleri Öğretmenleri Üzerine Bir Durum Çalışması, Yayımlanmamış Doktora Tezi, Çukurova Üniversitesi, Adana

Çınar, Orhan; Teyfur, Emine ve Teyfur, Mehmet (2006). “ilköğretim okulu öğretmen ve yöneticilerinin yapılandırmacı eğitim yaklaşımı ve programı hakkındaki görüşleri.” İnönü Üniversitesi Eğitim Fakültesi Dergisi, Cilt. 7, Sayı:11, ss. 47-64.

Çokluk, Ömay; Şekercioğlu, Güçlü ve Büyüköztürk, Şener (2012). Sosyal Bilimler İçin Çok Değişkenli İstatistik SPSS ve LISREL Uygulamaları. Pegem Akademi, Ankara.

Demir Başaran, Semra ve Keleş, Süleyman (2015). Yenilikçi Kimdir? Öğretmenlerin Yenilikçilik Düzeylerinin İncelenmesi, Hacettepe Üniversitesi Eğitim Fakültesi Dergisi, Cilt. 30, Sayı: 4, ss.106-118

Demiralay, Raziye - Bayır, Esma Aybike- Gelibolu, Mehmet Fikret (2016). "Öğrencilerin bireysel yenilikçilik özellikleri ile çevrimiçi öğrenmeye hazır bulunuşlukları ilişkisinin incelenmesi.” Journal of Research in Educatio nand Teaching, Vol.5, No:1, pp. 161-168. 
Demirkan, Özden ve Saraçoğlu, Gülçin (2016). “Anadolu Lisesi Öğretmenlerinin Derslerde Kullandıkları Öğretim Yöntem ve Tekniklerine İlişkin Görüssleri.” The Journal of International Lingual, Social and Educational Sciences, Vol. 2. No:1, ss. 1-11.

Durmuş, Aysun (2018). Yenilik Stratejilerinin İşletme Performansı Üzerindeki Etkileri Ve Bir Uygulama, Yayınlanmamış Yüksek Lisans Tezi, İstanbul Ticaret Üniversitesi Sosyal Bilimler Enstitüsü, İşletme Anabilim Dalı. İstanbul

Elçi, Şirin (2012). İnovasyon Rehberi: Kârlılık ve Rekabetin Elkitabı, İçinde Karata, Selçuk (Ed.). Yenilik - Yenileşim - İnovasyon Dünyasına Bir Yolculuk, (ss. 15-54), Ege Genç İş Adamları Derneği, İzmir.

Erden, Ali ve Erden, Hale (2020). The Relationship Between Individual Innovation and Social Entrepreneurship Characteristics of Teacher Candidates. International Journal of Curriculum and Instruction, 12(Special Issue), pp. 185-206.

Ergani, Kadir (2010) İlköğretim 4. ve 5. Sınıf Sosyal Bilgiler Dersi Öğretim Yöntem ve Teknikleri İle Materyal Kullanımına İlişkin Öğretmen Görüşleri, Yayınlanmış Yüksek Lisans Tezi, Dumlupınar Üniversitesi Sosyal Bilimler Enstitüsü, İlköğretim Anabilim Dalı, Kütahya.

Genç, S. Z., (2000). "Bilgi Toplumunda Öğretmen Eğitimi.” Kuram ve Uygulamada Eğitim bilimleri, Cilt. 23, ss. 375-386.

Genç, Salih Zeki ve Erayman M. Yunus (2007), "Değişen Değerler ve Yeni Eğitim Paradigması,” Sosyal Bilimler Dergisi, Cilt. 9,Sayı:1 ss. 90-103

Gürkan, Güney Çetin ve Demiralay. Tülay (2017). Bireysel Yenilikçiliğin Çalışanın Yenilikçi Davranışı Üzerindeki Etkisinde İçsel Motivasyonun Aracılık Rolü: Türkiye'de Cerrahlar Örneği. Girişimcilik ve İnovasyon Yönetimi Dergisi, Cilt. 6, Sayı:1, ss. 65-90.

İlter, İlhan (2014). “Öğretim Elemanlarının Kullandığı Yöntem ve Tekniklere İlişkin Öğretmen Adaylarının Görüssleri.” Journal of International Social Research, Cilt. 7, Say1:35, ss. 562-575

Karagöz Yalçın (2017). SPSS ve AMOS Uygulamalı Nicel-Nitel-Karma Bilimsel Araştırma Yöntemleri ve Yayın Etiği, Nobel Yayıncılık, Ankara.

Karasar, Niyazi (2005). Bilimsel Araştırma Yöntemi. Nobel Yayıncılık, Ankara. 
Karasu Avcı, Emine ve Ketenoğlu Kayabaşı, Esra Zehra (2019). "Sınıf Öğretmenlerinin Derslerinde Kullandıkları Yöntem ve Tekniklere İlişkin Görüsşleri: Bir Olgubilim Araştırması.” Hacettepe Üniversitesi Eğitim Fakültesi Dergisi Cilt. 34, Say1: 4, ss. 926-942.

Kayabaşı, Yücel (2012). "Öğretmenlerin Öğretim Sürecinde Kullandıkları Öğretim Yöntem ve Teknikleri ile Bunları Tercih Etme Nedenleri." Balıkesir Üniversitesi Sosyal Bilimler Enstitüsü Dergisi, Cilt.15 Say1:27, ss. $45-65$.

Kayabaşı, Yücel ve Özerbaş, Mehmet Arif (2019). "Sınıf Öğretmenleri ve Sınıf

Öğretmen Adaylarının Bireysel Yenilikçi Profillerinin

Karşılaştırması”. Türk Eğitim Bilimleri Dergisi, Cilt. 17, Sayı: 2, ss. 285303.

Kayasandık, Alp Eren (2017). “Öğretmenlerin Bireysel Yenilikçilik ve Değişime Hazır Olmalarının Algılanan Örgütsel Destek İle İlişkisi: Samsun'da Bir Çalışma.” Akademik Sosyal Araştırmalar Dergisi, Cilt. 5, Say1:54, ss. 511-527

K1lıç, Hasan (2015). İlköğretim Branş Öğretmenlerinin Bireysel Yenilikçilik Düzeyleri ve Yaşam Boyu Öğrenme Eğilimleri (Denizli İli Örneği). Yayımlanmamış Yüksek Lisans Tezi Pamukkale Üniversitesi Eğitim Bilimleri Enstitüsü, Denizli

K1lıç, Hasan ve Ayvaz Tuncel, Zeynep (2014). “ilköğretim Branş Öğretmenlerinin Bireysel Yenilikçilik Düzeyleri ve Yaşam Boyu Öğrenme Eğilimleri.” Uluslararası Eğitim Programları ve Öğretim Çalışmaları Dergisi, Cilt. 4, sayı:7, ss. 25-37.

Kılıçer, Kerem ve Odabaşı, Ferhan H. (2010). "Bireysel Yenilikçilik Ölçeği (BYÖ): Türkçeye Uyarlama, Geçerlik ve Güvenirlik Çalışması." Hacettepe Üniversitesi Eğitim Fakültesi Dergisi, Cilt. 38, ss. 150-164.

Kocasaraç, Hüseyin ve Karataş, Hakan (2018). "Yenilikçi Öğretmen Özellikleri: Bir Ölçek Geliş̧irme Çalışması.” Uşak Üniversitesi Eğitim Araştırmaları Dergisi, Cilt. 4, Sayı:1, ss. 34-57.

Koç, Canan. (2014). “Öğrenci Merkezli Öğretim Yöntem ve Tekniklerini Kullanmaya Yönelik Tutum Ölçeği: Geçerlik ve Güvenirlik Çalışması.” Elektronik Sosyal Bilimler Dergisi, Cilt. 13, Sayı: 49, ss. 150170. 
MEB (2005). İlköğretim Fen ve Teknoloji Dersi (4 ve 5. sınıflar) Öğretim Programı. Millı̂ Eğitim Bakanlığı Talim ve Terbiye Kurulu Başkanlığı, Ankara.

Naktiyok, Atılhan (2007). Yenilik Yönelimi ve Örgütsel Faktörler, İktisadi ve İdari Bilimler Dergisi, 21(2), ss. 211-230

Okur Akçay, Nilüfer; Akçay, Ahmet ve Kurt, Murat (2016). Ortaokul Öğretmenlerinin Öğretim Yöntem Ve Tekniklerine Yönelik Görüş ve Yeterliklerinin İncelenmesi. Eğitim ve Öğretim Araştırmaları Dergisi, 5(1), ss. 333-342.

Örün, Özgür; Orhan, Derya; Dönmez, Pelin ve Kurt, Adile Aşkım (2015), "Öğretmen Adaylarının Bireysel Yenilikçilik Profilleri ve Teknoloji Tutum Düzeyleri Arasındaki İlişkinin İncelenmesi.” Trakya Üniversitesi Eğitim Fakültesi Dergisi, Cilt. 5, Sayı:1, ss. 65-76.

Özdemir, Servet (2000). Eğitimde Örgütsel Yenileşme. Pegem A Yayıncılık, Ankara.

Özüsağlam, Erdal; Atalay, Ali ve Toprak, Salih (2009). WEB Tabanlı Anket Hazırlama Sistemi. XI. Akademik Bilişim Konferansı, (11-13 Şubat), Harran Üniversitesi, Şanlıurfa.

Patrick, Rachel (2003). Where Are Beginning Teachers' Stories about Learning to Teach in Culturally And Socially Diverse Secondary School Classrooms? Retrieved on 18/11/2019. at URL: https://www.researchgate.net/publication/228383173 pp. 1-16.

Rogers, Everett M. (2003). Diffusion of İnnovations (5th ed.). Free Press, New York.

Sansom, David W. (2017). Reinvention of Classroom Practice İnnovations. ELT Journal, Vol.71, No: 4, pp. 423-432, doi:10.1093/elt/ccw116.

Saraç, Mürüvvet (2019). Öğretmenlerin Yenilikçilik Düzeylerinin İncelenmesi, Tezsiz Yüksek Lisans Projesi, Pamukkale Üniversitesi, Eğitim Bilimleri Enstitüsü, Eğitim Bilimleri Anabilim Dalı Eğitim Yönetimi Bilim Dalı, Denizli.

Stevens, Robert J. (2004). "Why do Educational İnnovations Come And Go? What do We Know? What can We Do?” Teaching and Teacher Education, Vol. 20, pp. 389-396. 
Trapitsin, Sergey; Granichin, Oleg; Granichina, Olga ve Zharova, Marina (2018). Innovative Behavior of Teachers: Definition and Analysis. The European Proceedings of Social \& Behavioural Sciences, pp. 350-360, doi: 10.15405/epsbs.2018.12.02.37

Ünsal, Serkan (2017). "Felsefe Dersinde Aktif Öğrenme Tekniklerinin Kullanımı." Gazi Üniversitesi Gazi Eğitim Fakültesi Dergisi (GEFAD), Cilt. 37, Say1:3, 1013-1040.

Ünsal, Serkan; Çetin, Abdullah; Korkmaz, Fahrettin ve Aydemir, Mikail (2019). "The Change in the Curricula: Teachers' Perceptions," Çukurova Üniversitesi Eğitim Fakültesi Dergisi, Cilt. 48, Sayı:1, ss. 623-66.

Ünsal, Serkan; Ağçam, Reyhan ve Korkmaz, Fahrettin (2019). Prospective Teachers' Perceived Competence in the Use of Instructional Techniques: Evidence from Turkey. In E. Dobrescu (Ed.), Recent Ideas and Developments in Education, pp. 243-252.

Voogt, Joke and Pelgrum Hans (2005). “ICT and Curriculum Change.” Human Technology; An Inter Disciplinary Journal on Humans in ICT Environments, Vol.1, No:2, pp. 157-175

Yatağan, Murat (2014). Fen ve Teknoloji Dersi Öğretim Programinin Öğrenci Ve Öğretmen Özelliklerinne Göre Değerlendirilmesi: TIMSS 2007 ve 2011 Verileri ile Bir Durum Analizi. Yayımlanmamış Doktora Tezi, Gazi Üniversitesi, Eğitim Fakültesi, Ankara.

Yenice Nilgün ve Tunç Alpak Gizem (2019). “Öğretmen Adaylarının Yaşam Boyu Öğrenme Eğilimleri ile Bireysel Yenilikçilik Düzeylerinin İncelenmesi." Kastamonu Eğitim Dergisi, Cilt. 27, Sayı:2, ss. 753-765.

Yeşilpınar Uyar, Melis ve Doğanay, Ahmet (2018). “Öğrenci merkezli strateji, yöntem ve tekniklerin akademik başarıya etkisi: Bir meta-analiz çalışması.” Mersin Üniversitesi Eğitim Fakültesi Dergisi, Cilt. 14. Sayı:1, ss. 186-209. DOI: 10.17860/mersinefd.334542

Yıldırım, Ali ve Şimşek, Hasan (2011). Sosyal Bilimlerde Nitel Araştırma Yöntemleri. Seçkin Yayıncılık, Ankara. 